\title{
Generation and Diffusion of Innovations in a District Innovation System:The Case of Ink-Jet Printing
}

\author{
Yolanda Reig-Otero', Mónica Edwards-Schachter², Carlos Feliú-Mingarro ${ }^{3}$, Ignacio Fernández-de-Lucio ${ }^{4}$
}

\begin{abstract}
This paper provides an in-depth case study of the ink-jet printing (IJP) technology that emerged from the ceramic industry in a Spanish region (Castellon) in the first decade of 2000. We propose an analytical framework that combines the theoretical perspectives of Industrial Districts and Innovation Systems, and exploit a qualitative methodology that includes information from patent and scientific article databases and $2 \mathrm{I}$ in-depth interviews. Our results show that IJP is a major innovation that breaks with the tradition of machinery innovations in this industry in Spain. Micro-level evidences show the complex external and internal relationships in the sharing of knowledge and innovation process, being the role of internal ties, trust, secrecy and strong in-house R\&D strategies determinants of the IJP innovation.
\end{abstract}

Keywords: innovation process; innovation system; industrial district; learning region; ceramic tile industry; ink-jet printing.

\footnotetext{
1,3 Instituto de Tecnología Cerámica (ITC). Campus Universitario de Riu Sec. Avd. Sos Baynat S/N. CP I2006-Castellón de la Plana.

${ }^{2,4}$ INGENIO (CSIC-UPV), Universitat Politècnica de València. Ciudad Politécnica de la Innovación, Camino de Vera S/N, Ed. 8E Acceso J, 46022-Valencia,TE 963877007 Fax 96387799I. Mónica Edwards-Schachter, principal contact for correspondence: moed@ingenio.upv.es
} 


\section{Introduction}

Regional agglomerations of industrial activity have long been recognized as potential sources of innovation, and important for successful economic development (Cooke, 1996; Malerba, 2002; Becattini et al., 2009). Since the contributions of Lundvall (1992), Storper (1993, 1997), and Asheim (1996, 2007), among others, greater attention has been paid to the roles of learning and systemic interactions in the process of generation and diffusion of innovation as determinants of regional technological and economic performance. Despite extensive research on innovation in clusters and Industrial Districts (ID) that draws on evolutionary economics approaches, our understanding of how innovation emerges and evolves in them at meso and micro-level is relatively poor (lammarino, 2005; Malerba and Vonortas, 2009; Cantner et al., 2010).

This paper provides an empirical research from the microlevel perspective which in Spain is scarce (Molina-Morales, 2002; Boix and Galleto, 2006; Boix, 2009), presenting a case study of an innovation that emerged in the Castellon region in the first decade of 2000: that is, Ink-jet Printing (IJP) technology. This technology has been described as part of a 'digital revolution in the ceramic industry' (FERRO, 200 I; Hutchings, 2009; Giacomini, 2010). The Castellon region concentrates over $90 \%$ of Spanish ceramic tile production (Escardino, 200I; Tortajada et al., 2008). Over the years, various printing techniques have been used to decorate tiles. Traditional contact printing methods include screen printing, flexography and rotogravure (De Carlo and Montani, 2003; Berto, 2007; Clymer and Asaba, 2008). Several authors point to innovations in ceramic tile decoration enabled by the introduction of IJP technology is opening new opportunities in the ceramic industry and other economic sectors (Hutchings, 2009; Moreno et al., 2010; Sanz et al., 2012). This study analyses the generation and development of the IJP innovation from the perspective of ID, LRIS and learning regions (Becattini, 1990; Storper, 1993, 1997; Florida, 1995; Asheim, 1996, 2007; Sforzi, 2006). Specifically, we apply an evolutionary theoretical lens to technological change in relation to the following dimensions: I. absorption of new knowledge (including exploration and acquisition of available knowledge); 2. generation of new knowledge, technology and innovation; and, 3. diffusion of innovation throughout the regional 'learning system' (Evangelista et al., 2002; Caniëls and Romijn, 2003; lammarino, 2005; lammarino and McCann, 2006; Moodysson et al., 2008; Herrschel., 2010). Our main research questions are related to:

- the nature (type, characteristics) and dynamic of the knowledge flows and drivers of the learning process in IJP technology;

- $\quad$ the agents involved in IJP technology generation;
- the generation, appropriation and diffusion of IJP technology.

Our principal purpose is to provide micro-level (individuals and firms involved in the innovation processes) empirical evidence and contrast it to the findings in the research literature. The paper is organized as follows. Section 2 describes the theoretical framework of ID as an innovation system and a local learning system. Section 3 describes the research context and the structure of the Castellon Ceramic District Innovation System (CCDIS), Section 4 discusses the research methodology and Section 5 presents the results of the case study. Section 6 concludes the paper.

\section{Regional dynamics in the micro-level: combining in- dustrial district and innovation system approaches}

The term 'region' takes on different meanings in different disciplines and may embrace sub-national and inter-national spaces, and can be associated with several conceptual constructs such as clusters, districts, milieus innovateurs, new industrial spaces and local production systems (Brusco, 1990; Belussi, 1996; Cooke, 2009; Porter and Ketels, 2009). Cooke (200I) proposed two distinct definitions of region: a) a geographically-defined, administratively-supported arrangement of innovative networks and institutions that interact with innovative outputs of firms on a regular basis, and b) a 'socio-cultural' entity or a series of cultural aspects related to the concept of embeddedness, which emphasizes systemic interconnectedness and interdependency. Lundvall and Borrás $(1997,39)$ affirm that 'the region is increasingly the level at which innovation is produced through regional networks of innovators, local clusters and the cross fertilising effects of research institutions'. From this point of view, a basic premise of the regional innovation system (RIS) approach is that regional innovation performance depends directly on the systemic character of the region's innovation activities, which involve complex and dynamic external and internal relationships. A RIS should be considered to be an integrated system consisting of components, relations and attributes, that is, a set of networks of public and private agents that interact and provide mutual feedback within a specific territory, and exploit the internal dynamics of regionally embedded socio-cultural, economic and institutional structures in order to adapt, generate and extend knowledge and innovation (Evangelista et al., 2002; Buesa et al., 2005; lammarino, 2005; Buesa and Heijs, 2007). Clusters and RIS are also closely related. It is commonly argued that clustered firms - particularly in the case of Small and Medium Enterprises (SMEs)- enjoy advantages in terms of innovation performance through processes of localized learning. This means that clusters and RIS may co-exist in the same territory and the regional innovation system may in fact contain several clusters. Doloreux (2002) claims that the RIS 
encompasses a normative and a descriptive approach that aims to capture how technological development takes place within a territory. From an evolutionary perspective on economic development and technical change (Dosi, 1982; Nelson, 1995; lammarino and McCann, 2006) the theory of RIS stresses the role of 'collective learning', which, in turn, refers to deep, cooperative and competitive relationships among system members (Cooke and Morgan, 1993; Edquist, 1997). In this perspective, innovation is the result of a process that includes acquisition, generation/recombination, diffusion and use of knowledge, in which the interaction between the agents in the process (built on feed-back), cumulative aspects, problem-solving, knowledge capabilities, among other aspects, are evident (Lundvall, 1992, 2007; Cooke, 2005; Sforzi, 2006).

Herrschel (2010) and Cantner et al. (2010) highlight the role of social networks and interactions at several levels within the regional system (e.g., intra- and inter-firm) and across system borders. Although the barren debate over the conceptual differences between clusters, IDs and RIS (Harrison, 1992; Moulaert and Sekia, 2003; Heidenreich, 2005; Porter and Ketels, 2009) the definition of LRIS covers all these theoretical constructs in the sense that all are founded on the idea of 'networking' (Cooke and Morgan, 1993; Vonortas, 2009; Cantner et al., 2010). In this respect, research on ID and clusters is moving from a predominantly static approach to more dynamic analysis to understand how spatial concentrations and networks emerge and evolve along time (Gordon and McCann, 2000; Lorenzen, 2005; Braunerhjelm and Feldman, 2006; Zirulia, 2009). In this paper we investigate innovation linking the notions of ID (sectoral and regional) innovation systems and learning regions, by developing an analytical approach that combines innovation systems theory related to the generation and dissemination of knowledge (learning) with relational interactions among agents in a socio-cultural space. We adopt the concept of
District Innovation System (DIS), which includes all these aspects to explore the Castellon region free of the empirical constraints of concepts of clusters and ID, which tend to focus on horizontal and vertical linkages and cooperation within the location, but overlook the role of external linkages (Motoyama, 2008; Gabaldón et al., 2009). Figure I depicts the definitions, elements, characteristics and complementarities that converge in the DIS approach. We consider the 'relational assets' or 'untraded interdependencies' as sources of learning that enable certain regions to innovate and adapt effectively to changes in the external market environment (Storper, 1997).

DIS can be seen as an evolution of social and economic 'selforganized' systems based on recursive interactions among their components and with the environment (Belussi, 1996). DIS can also be considered cognitive systems whose knowledge background comprises firms' and territories' learning mechanisms and knowledge creation processes. This contextual knowledge is not easily replicable and it is important to investigate the 'learning' processes that configure the cognitive system and how the combination of different types of knowledge occur (Asheim, 2007; Moodysson et al., 2008). Our approach allows an examination of the evolution of innovation through a study case of the CCDIS that takes account of the relational and socio-cultural embeddedness in 'slippery' spaces. Knowledge is a mixture of experience, values, contextual information and insights, which create a framework for assessing and incorporating new experiences and information (Davenport and Prusak, 2000). Knowledge flows can occur through several sources, learning mechanisms and instruments, embracing individuals and inter-firm interactions, formation of new enterprises and mobility of skilled personnel among firms (Keeble and Wilkinson, 1999). The learning environment and innovation processes are shaped strongly by knowledge bases and absorption capabilities (Cohen and Levinthal, 1990; Asheim, 2007; Moodysson et al., 2008).

\section{DIS: characteristics, elements of analysis and complementarities}

\section{ID}

firm agglomeration (particularly SMEs) people community

patterns of technological specialization accumulation of skills and know-how

industrial 'atmosphere'

historical, geographical and cultural factors

role of interactive learning and tacit knowledge

cooperation and competitiveness

relationships between actors

supporting and active role of external

institutions

\section{RIS}

a production structure embedded in an institutional structure (administrative, political, legal, educational, etc.) networks and interactions of actors and institutions (including internal and extra-region linkages)

focus on knowledge generation, recombination and diffusion

localized knowledge sharing (inter-individual, intra and inter-organization)

historical path dependency of localized

innovation processes

\section{LEARNING REGION}

territorial and institutional embeddedness of learning organizations and interactive learning

spatial phenomena related to knowledge and cognitive system (cognitive distance)

focus on social capital and human capital and

their interrelationships with learning

knowledge basis (analytic, syntethic and

symbolic)

capabilities and competences building

tacit knowledge and untreated

interdependencies

Figure I.The DIS approach (Source: own elaboration)

ISSN: 07 I8-2724. (http://www.jotmi.org)

Journal of Technology Management \& Innovation (c) Universidad Alberto Hurtado, Facultad de Economía y Negocios. 


\section{The Castellón Ceramic District Innovation System (CCDIS)}

Previous studies of the ceramic industry in the Castellon region focus on particular aspects of the phenomenon of innovation using the concepts of cluster, ID or a combination of both approaches (Ybarra, 199I; Molina-Morales et al., 2002; Molina-Morales and Martínez-Fernández, 2009a; Expósito-Langa and Molina-Morales, 2010).According to the literature strong sectoral cohesion, highly skilled human resources, optimal use of technological resources and support from public and private institutions are the main factors that contribute to the development and economic success of the Castellon region (Escardino, 200 I; Molina-Morales et al., 2002; Barba, 2005).

Figures 2 and 3 show the structure of the CCDIS and its agents: final firms (ceramic tile manufacturers), frit, glaze and colour suppliers, machinery and other services providers (manufacturers of trims, design, logistics, distribution, etc.). The CCDIS is organized around a set of very active producer associations that perform various activities such as training, commercial promotion, technical support, legal services and lobbying. The ITC (Instituto de Tecnología Cerámica, Institute of Ceramic Technology) has links to the AICE
(Association for Research in the Ceramic Industries) and is managed jointly by the local University Jaume I, the ceramic firms through ASCER (Ceramic Tile Trade Association) and regional government through IMPIVA (a regional industrial policy agency). The ITC employs around 100 scientists and has links with other smaller laboratories, such as the $\mathrm{S}$. Carpi quality laboratory, and design groups such as ALICER (Association for Ceramic Promotion and Design). Some of these organizations -e.g. AICE and ASCER- are national as well as regional.

ITC (Institute of Ceramic Technology), ASCER (Spanish Association of Ceramic Tile Manufacturers), ANFFECC (Spanish Association of Frit and Glaze Manufacturers), ASEBEC (Spanish Association of Ceramic Machinery and Equipment Manufacturers), ATC (Association of Ceramic Technicians), ALICER (Association for Ceramic Promotion and Design), FUE (University-Companies Foundation), representatives of ANDIMAC (National Association of Ceramic Distributors and Construction materials, Asociación Nacional de Distribuidores de Cerámica y Materiales de Construcción) and SECV (Spanish Society of Ceramic and Glaze, Sociedad Española de Cerámica y Vidrio), CEVISAMA (Annual sector fair) and QUALICER (Tile Quality World Biennial conference).

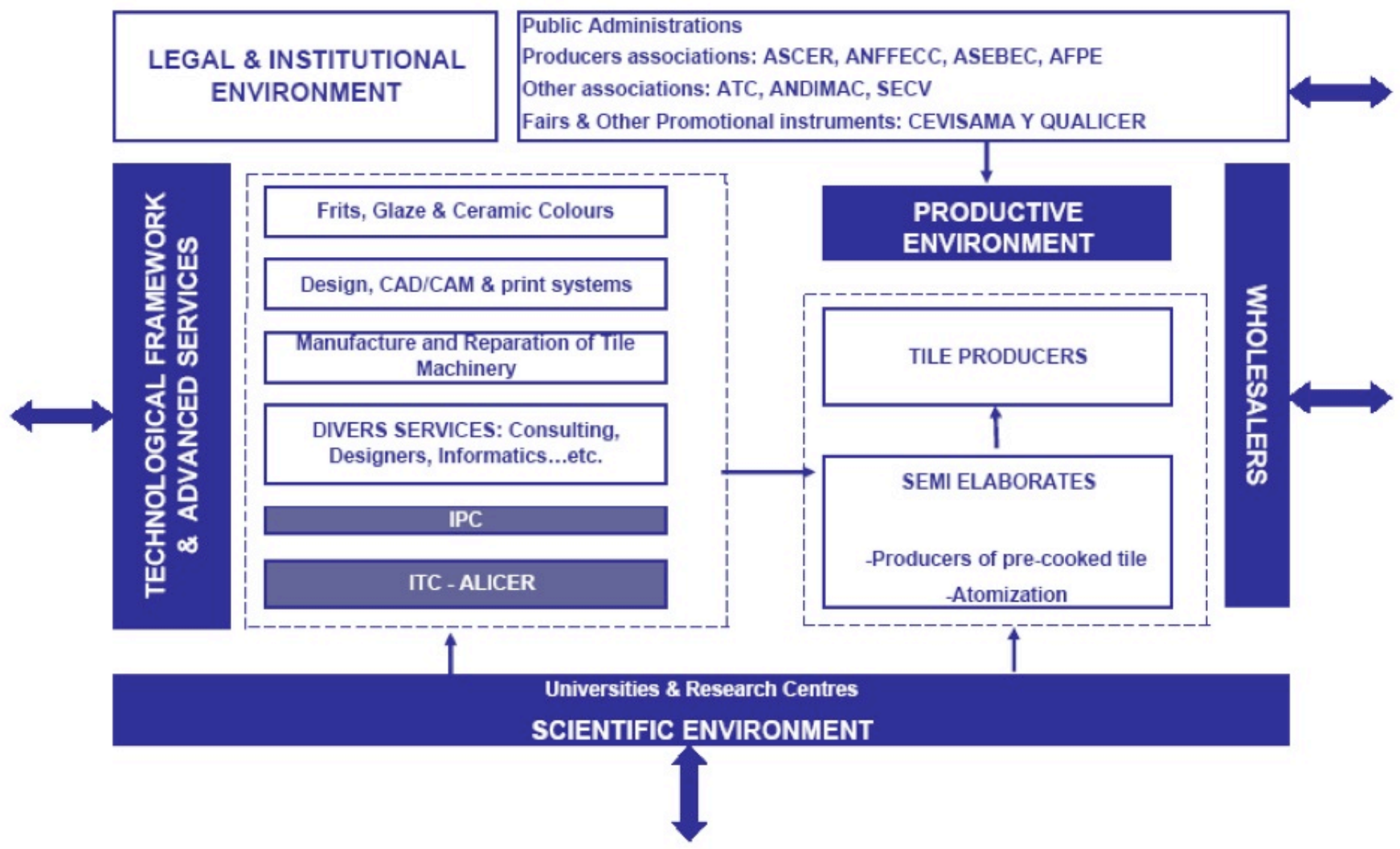

Figure 2. Global picture of CCD system.

ISSN: 07 I8-2724. (http://www.jotmi.org)

Journal of Technology Management \& Innovation (c) Universidad Alberto Hurtado, Facultad de Economía y Negocios. 
The CCDIS is characterized by dynamism based on its technological product and process innovations in materials, machinery and frit, glaze and colour. Several studies highlight the predominance of technological innovation in the frit and glaze sub-sector (Escardino, 200I; MeyerStamer et al., 2004; Tortajada et al, 2008; Gabaldón et al., 2009). A study by Gabaldón et al. (2009) shows that patenting activity in the CCDIS is mostly in this sub-cluster and that ceramic tile producers are generally involved in non-technological innovations.

Innovation processes are originated in the collective actions of a number of firms and actors that are connected by networks, informal contacts and a common knowledge base. Knowledge is acquired and diffused through personal contacts among firm members, suppliers, users, research centres and other actors, facilitated by local proximity in an environment of close cooperation-competition relationships (Molina-Morales, 2002). Proximity among the actors facilitates the building of an environment characterized by frequent contacts and formal and informal relationships building a particular environment, i.e., 'industry is in the air'. Constant flows of information and new knowledge promote a continuous stream of incremental innovations based on combinations of tacit and codified knowledge and experience of learning by doing. Although no single firm in the ID controls or possesses all these resources they are unavailable to firms outside the cluster. Molina-Morales et al.
(2002) show that product or process improvements are a collective endeavour that cannot be assigned to a single firm or institution. Forms of legal protection such as patents, copyrights or licences are rare in the CCDIS and suggest the existence of non-contractual protection mechanisms based on the firms' social embeddedness. However, studies from the perspective of social capital (Molina-Morales and Martínez-Fernández, 2009b; Expósito-Langa and Molina-Morales (2010) argue against a simplistic association between knowledge diffusion and proximity within a district, and propose that while proximity facilitates trust in internal relations it simultaneously hinders access to external sources of knowledge. These authors highlight the role of local institutions -particularly the ITC- as repositories of relevant knowledge and intermediaries that can provide access to external networks and exploration of new opportunities.

\section{Methodology}

We adopt a qualitative approach and a case study methodology, in which the technological innovation (IJP) produced by the CCDIS is the unit of analysis. A case study is a history of a past or current phenomenon, that draws on multiple sources of information and evidence. It is a powerful instrument that captures the complex dynamic of the innovation process (Eisenhardt, 1989; George and Bennett, 2005). We describe the innovation process and the events and relationships leading to the emergence of the IJP technology. They

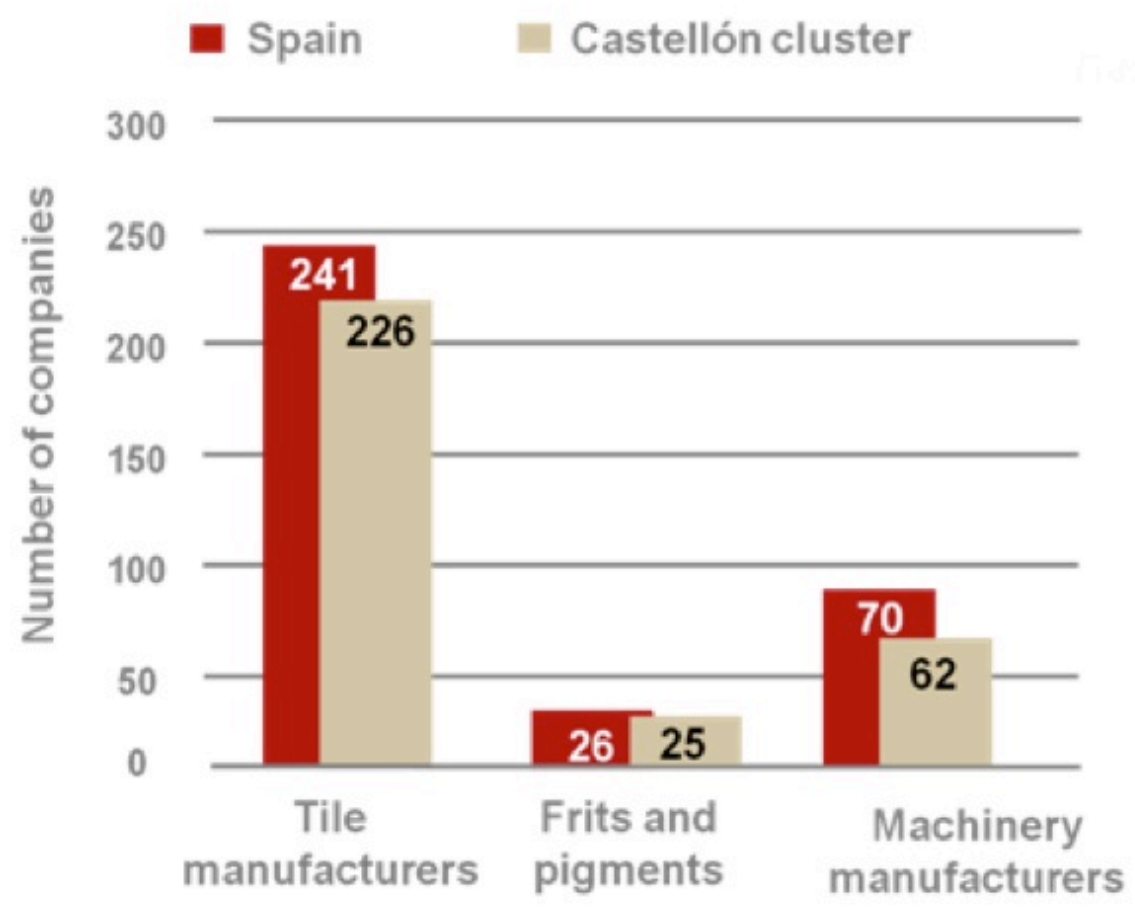

Figure 3. Cluster and sub-clusters (agglomerations of firms) at the CCDIS. (Source: ITC, 20II)

ISSN: 07I 8-2724. (http://www.jotmi.org)

Journal of Technology Management \& Innovation (c) Universidad Alberto Hurtado, Facultad de Economía y Negocios. 
are constituted by a series of interdependencies and a wide range of actors and temporary or informal relationships, which are difficult to capture. This allows us to take account of how a phenomenon is influenced by its context and to gather data from a variety of sources. Specifically, we considered patents, scientific articles, and secondary documents such as organization reports and technical articles from the literature (Web of Science, Scopus, Ceramic abstracts, etc.) and the information in patent databases (Esp@cenet, la Oficina Española de Patentes y Marcas (OEPM, Spain); PAJ and the Derwent Innovation Index) using the Matheo Patent software (Breschi and Lissoni, 2004). We consulted the annual reports of Gold Alfa's Award of the Spanish Society of Ceramics and Glass (Sociedad Española de Cerámica y Vidrio, 2010), which is a prestigious annual award that has been presented at the CEVISAMA Fair since 1975 in recognition of the most important innovations in the sector. To obtain an in-depth understanding of the sector we conducted $2 \mathrm{I}$ interviews during January to July $20 \mathrm{II}$, with the principal actors involved in the generation, development and diffusion of the IJP technology using an hermeneuticdialectic method where the interviewer played an active role, and interviewer and respondent shaped the interview 'content' together (Jørgensen and Phillips, 2002). The selection of items was based on feedback from a panel of experts and some pilot questionnaires.

\section{Origins, development and diffusion of the IJP tech- nological innovation}

IJP technology refers to a variety of techniques used to generate droplets of ink which are propelled towards a predetermined surface. They include several IJP techniques such as continuous (binary, multi-level, greyscale), drop-on-demand (DOD)/valve jet (shutter, array) and impulse jet (activated and chevron), among others (Wijshoff, 2008; Garnsey et al., 2010). The IJP industry emerged in the 1970s, disrupted the dominant design of dot matrix desktop printing in the late 1980s, entered a growth phase in 1990 related to office computer system applications, and reached maturation at the end of the 1990s (Hutchings, 2009; Garnsey et al., 2010). When development was transferred to the industrial field, various issues emerged that made complicated technology transfer and development (Sanz et al., 20 I2). The first studies of IJP technology applied to fine ceramic decoration were conducted in 1980 by W. Roberts of British Ceram Research Ltd (UK). For some 10 years research focused on the adaptation and upgrading of ink properties, particularly flowability and conductivity, and testing of different printing methods and substrates (Seong-Jim and Mckean, 1998). Developments in IJP technology as a new method of decoration on an industrial level appeared in 1997 in the Castellon region. To explore the history of this technology we ran database searches using some general keywords, such as inkjet, ceramic, tile, etc., identifying documents related only to ceramic tile manufacture and rejecting applications for the design and manufacture of printed circuit boards, ceramic processing tools and fine ceramics, etc. (e.g. a patent registered in 1975 mentions the IJP technology in reporting a procedure for flexographic printing). Figures 4 and 5 show the number of patents and scientific articles published between 1975 and $201 \mathrm{I}$.

Analysis of patents shows that finding appropriate inks was critical for the development of the IJP technology in the ceramics industry because ceramic inks have certain particularities and properties. Their most important characteristics are: (a) high levels of stability and precipitation; agglomeration and changes in viscosity can clog the injectors (about $50 \mu \mathrm{m}$ ); (b) strong tints, such that small amounts can cause problems in the substrate $(7-70 \mathrm{pL})$, may decrease the intensity of the colours achieved and result in poor quality decoration (surface tension, drying rate of the drop); (c) neutral $\mathrm{pH}$ required to prevent corrosion of the heads, (chemical compatibility between nozzle and the ink). Information obtained from the interviews shows the non-linearity of the innovation process, and the level of secrecy and competition among firms in the search for an appropriate ink.

The first IJP machine prototype for the ceramic tile industry was introduced in 2000; its inventors received the Gold Alfa Award of thepanish Society of Ceramics and Glass. The period 2000-2005 saw the development of several prototypes and the first commercialization and diffusion of the technology in the ceramic sector. The first industrial IJP machine was developed by José VicenteTomás Claramonte (JVTC), owner of a small supplier company dedicated to computer engineering for ceramics in Villarreal, a town with a long tradition of ceramic tile manufacture in the CCDIS. He bought a print-head and conducted printing tests with Rafael Vicent Albert (RVA), an engineer working in the firm, and Antonio Querol, a chemical engineer who was working in the R\&D department of Ferro Enamel Española S.A., a subsidiary of the Spanish multinational Ferro Corporation.

\section{First stage: exploration and absorption of knowledge}

Several technicians and engineers working in different firms were keen to introduce this technology, but the complexity, and the high cost of the research related to raw materials and inks required to adapt printheads for use on an industrial scale, made this new technology unpopular. One of the inventors of the ink jet printer (AQ) we interviewed commented that:

'all people had the idea ... the idea of this development was in the air ... the possibility of printing ceramic surfaces in similar forms that in paper or board ... we knew 
about some intents and proofs but it was a very complex problem, requirements of ceramic materials are very different' ( $A Q$, inventor).

The developers attended to the Drupa Fair, the world's biggest printing equipment exhibition in the world, held every four years in Messe Düsseldorf in Germany. They observed 'Many people worked in ink-jet printing in imaging and graphic arts... IBM mixed flexography ... curiously all developments led to a long and large print-head, only INCA [a firm] attempted to develop digital plotters and a single-pass printer' ... 'Our proposal can be distinguished from these alternatives due we provide a new technological solution, we proposed a single-pass mechanism which defined the stateof-the-art and this idea was attractive and viable at industrial scale' (RVA, developer).

'The inks were the main constraint because the particle size of the pigments was stable and formed agglomerates larger than the size of the injector nozzle which is approx. $50 \mu \mathrm{m}$. Although we were thinking of obtaining soluble inks, there were no appropriate solvents or additives' (AQ, inventor).

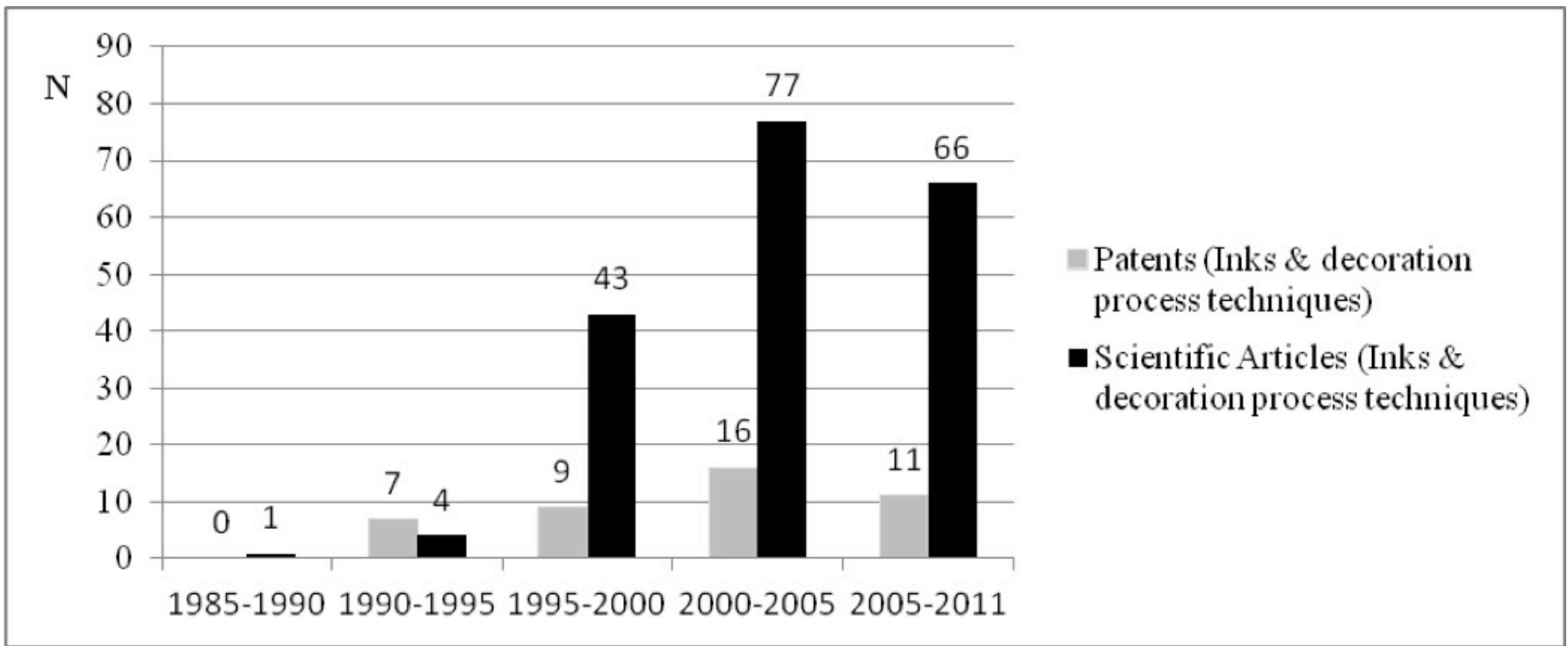

Figure 4. Number of patents and scientific and technical journal articles published on inks and decorative techniques for IJP technology in the ceramic tile sector (we consider five-year time intervals before and after the first machine exhibition at the CEVISAMA Fair)

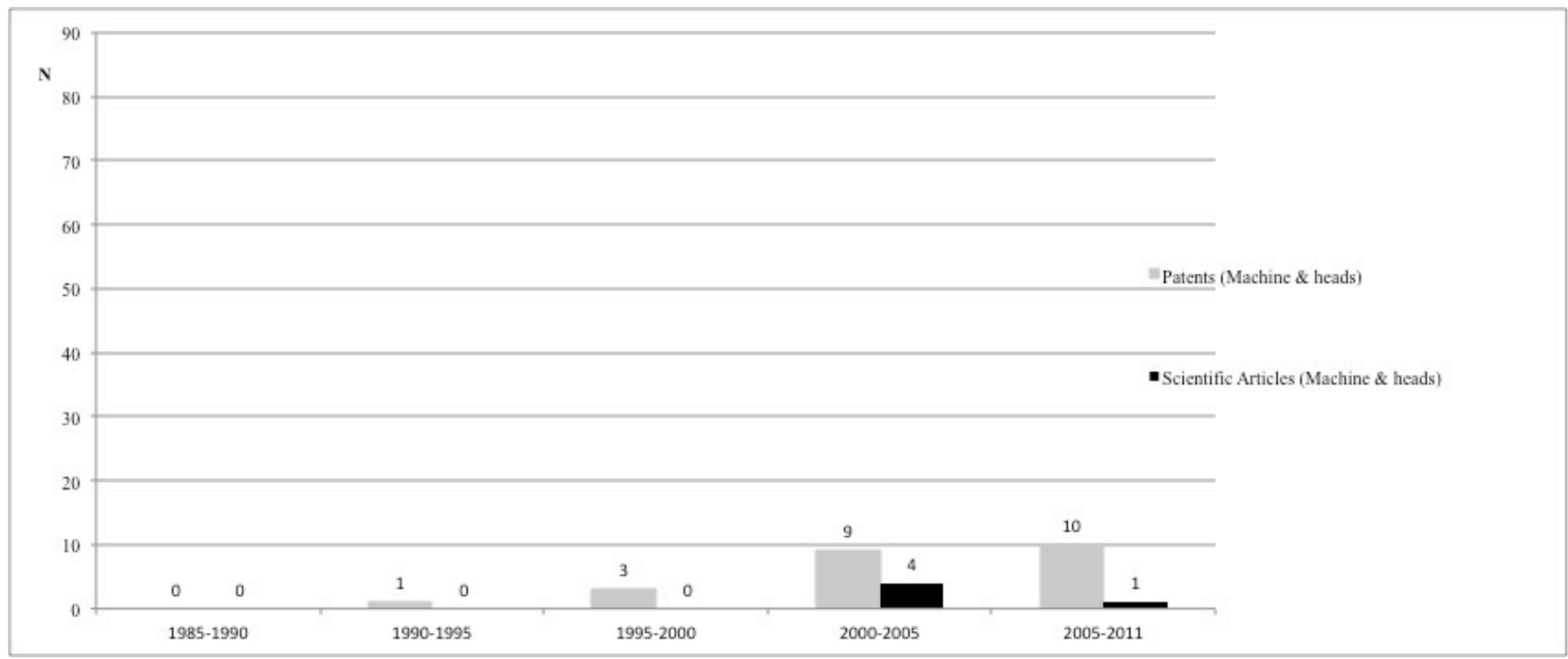

Figure 5. Number of patents and scientific and technical journal articles published on development of print-heads and machines for IJP technology in the ceramic tile sector

ISSN: 07I 8-2724. (http://www.jotmi.org)

Journal of Technology Management \& Innovation (c) Universidad Alberto Hurtado, Facultad de Economía y Negocios. 
This milestone in the development of IJP technology corresponds to the phase of 'sequence of problems' and 'autocatalysm of knowledge' related to resolution of an initial problem (Coombs et al., 2003). The process was described by one of the inventors:

'we began to experiment with different printheads to find more appropriate soluble salts, doing hundreds of tests ... but the problem was that printheads do not allow the use of water which damages the electrodes, and using other solvents we found they attacked the adhesives that linked the piezoelectric material to the printheads' (RVA, developer).

According our study, we identified five firms, four in the CCDIS and one in France attempting to adapt printheads and solve the problems related to limitations in the inks characteristics.

'Other technicians tried to create a machine using propellants with soluble inks but they failed ... 'there were other attempts in France and in other firms in Castellón. I think that they saw the opportunity considering our dependency from the Italian industry ... the decorating machines were monopolized by Italians and for each drawing design we had to make four rolls of silicone' ... 'This invention was very secret but here [in the CCDIS] we get information through a web of networks of friends' ... 'we all knew the problem with the inks ...' (VS, researcher at ITC).

The literature shows that radical innovations and innovations with a high degree of originality and 'radicalness' face more obstacles to acceptance by industry (Expósito-Langa and Molina-Morales, 2010). During the first trials with printheads, JVTC presented his ideas for developing ink jet printing to a number of companies in the sector, but none of them considered the development feasible. He and his friend travelled to the Cambridge ink jet cluster and presented their ideas to the then CEO of Cambridge Consultants Ltd., which is linked to the Xaar Group from which they acquired their first printhead. However, the Xaar Group also was not interested. In contrast to the findings in the literature (Morales and Martínez-Fernández, 2004; Expósito-Langa and Molina-Morales (2010) the innovation in our case came from a small firm which avoided the contacts with local research institutions that might have acted as information suppliers, like the ITC and the university placed in Castellón.

\section{Second stage: new knowledge generation}

Our interviewees confirmed that the main constraint for this technological development was inks which constituted a paradigm shift in research lines related to studies and development of nanoinks and nanopigments.
'In the industry there was a myth about the size of the pigment particles ... we would not go down to the microscopic size the pigments powder disappeared' (EA, CDTI).

After several months of experimenting with hundreds of pigments through trial and error, JVTC and his partners were able to demonstrate the viability of the inks R\&D to Ferro Enamel Española SA, a subsidiary of Ferro Corp. in Castellón. Ferro's long (92 years) experience as a leading global supplier of technology-based materials for a broad range of manufacturers, and its well established R\&D activity with ample knowledge and experience in inks. The reciprocity and strong trust among the three developers were key for the development of IJP technology, they set up a company called KERAjet to conduct R\&D for the developing all the requirements: electronics, software and inks (Ferro, 200I).

'The R\&D activities began in December 1998, when we managed to print a first tile with Xaar (printhead) with a photograph of my daughter' (AQ, developer).

Thus Ferro Enamel Española SA, attracted by local opportunities, acted as a 'learning interface' (Belussi and Asheim, 2010) and intermediary between Enginyeria PC and and Seiko, a printheads supplier from Japan. Confidence, cooperation and secrecy were crucial in this stage of the IJP development, being the first machinery innovation that broke with the tradition in Europe of machinery innovations originating in Italy.

' $\mathrm{J}$ is an entrepreneur and a very good engineer but he didn't know about problems with inks. Ferro provided him with the necessary knowledge on inks... Ferro also solved his problems with Xaar heads that were not functioning properly, [Ferro] made possible the contact between Seiko, a leading manufacturer of print heads in the world, and JV' (VS, researcher at ITC).

KERAjet worked with two printheads developed by external firms: Xaar (UK) and Seiko (Japan). Xaar printheads, which are used for high quality printing, do not have to run at such high speeds on line and do not involve very dark colours; Seiko's printheads are used for high quality printing in multiple colours, for high speed glazing lines and for very deep-coloured tile production. On 14 October 1998 JVTC applied for a patent at the Spanish patent office and on 27th September 2000 sent an application to the European Patent Office. The patent described a device comprising at least two independent print modules easily replaceable with a single-pass mechanism, where only one pass is needed to complete the decorative motif (Tomás Claramonte, 1999, p. 2). This characteristic allows considerably faster printing speed (with a print quality of $200 \mathrm{dpi}$ ). The first IJP prototype had 20 print heads with a printing width of up to $700 \mathrm{~mm}$ and 
images up to $1.365 \mathrm{~cm}$ wide at speeds of $50 \mathrm{~m} / \mathrm{min}$. Two of the machine's inventors said that the multiple printheads and the single-pass method distinguished it from other technological solutions which mostly used single head systems. A major problem in this first development was achieving yellow and brown colours, which are in high demand from the ceramic sector. In 200I, Ferro Corp. patented a 'New yellow ink for the decoration of ceramics and glass using inkjet technology' (Querol Villalba and Guaita Delgado, 2002). Between 2000 and 2003 various competitors in the CCDIS made unsuccessful attempts to deploy the IJP technology using soluble inks applying the DOD (drop on demand) and $\mathrm{ClJ}$ (continuous ink jet) methods. In 2004, Ferro introduced the INK$\mathrm{CID} \otimes$ system based on pigment inks. Tables I and 2 (Annex) present the principal technological and scientific knowledge contributions in the form of patents and scientific articles, related to the development of IJP technology.

\section{Third stage 3: IJP technology diffusion}

Technological diffusion is the process by which innovations whether new products, new processes or new management methods- spread within and across markets and economies. There are two stylized facts related to technological diffusion: spread - the S-curve - when diffusion rates gradually rise and then fall over time. There is a period of relatively rapid adoption sandwiched between an early period of slow take up and a late period of slow progress to satiation); and economic and social factors. Economic and social factors influence individual decisions to begin using the new technology based on the costs and benefits of its adoption. The benefits of IJP technology compared with previous decorating techniques, such as gravure printing and flat screen-printing technologies, were undisputed. However, its diffusion in the ceramic sector was not as rapid as expected. There were problems related to the stability and low chromatic intensity of the inks for application in an industrial process. These aspects and the high price of materials ( $\mathrm{Ru}, \mathrm{Au})$ acted as barriers to the rapid expansion of IJP technology in the CCDIS. KERAjet SA intensified its research efforts on colour range and intensity and ink and enamel stability in order to obtain acceptable colours.

'The road was to investigate intensely pigment inks, with inorganic pigments in its composition and the characteristics required for this process' (AQ, developer).

IJP technology began to spread in the ceramic sector after the appearance of a new option on the market in 2005. Torrecid, a multinational frit, glaze and ceramic producer,

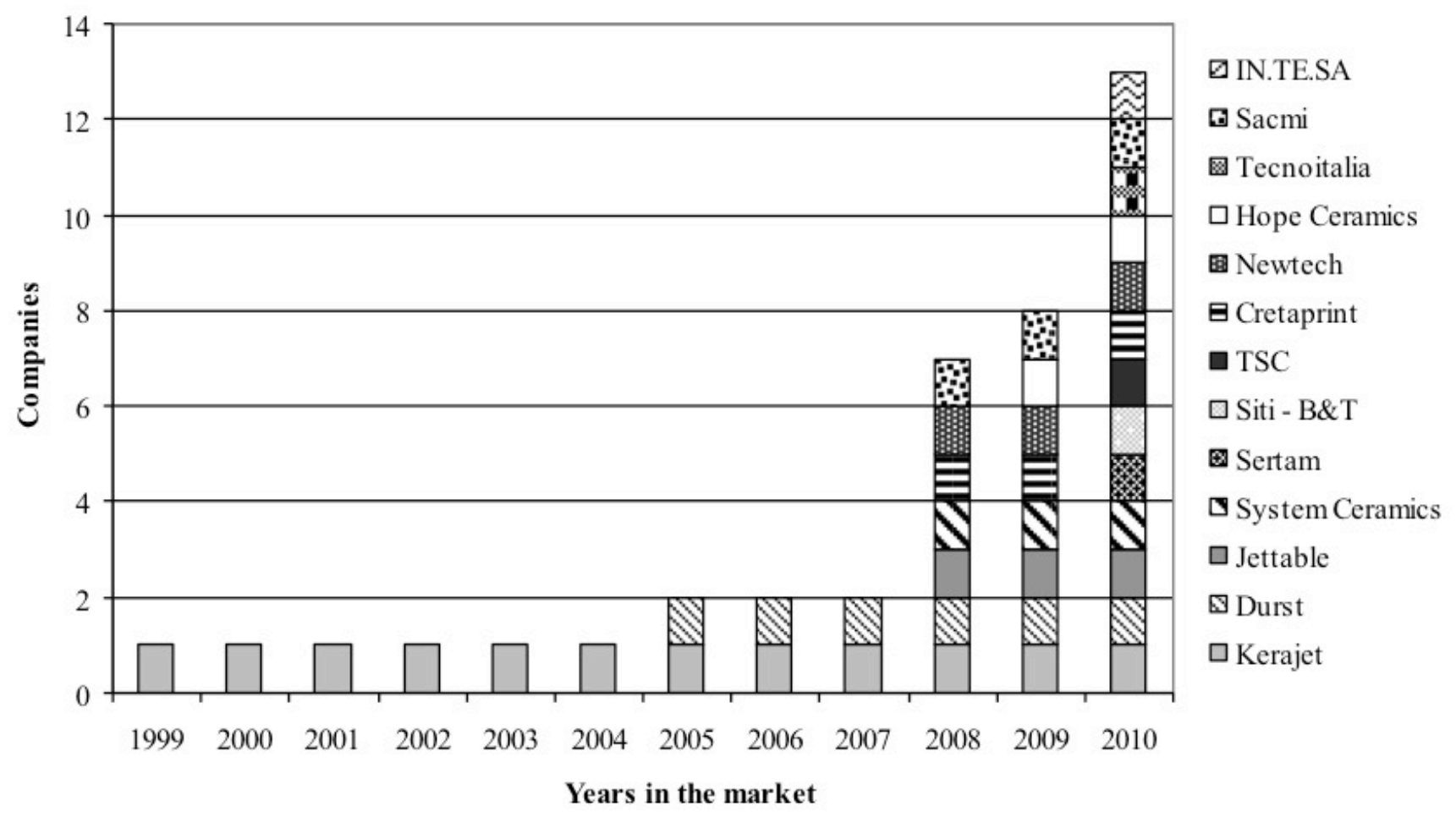

Figure 6. Number of companies manufacturing ink systems and machines for IJP technology for the ceramic tile industry (Source: Giacomini, 20II)

ISSN: 07 I8-2724. (http://www.jotmi.org)

Journal of Technology Management \& Innovation (c) Universidad Alberto Hurtado, Facultad de Economía y Negocios. 
launched a range of pigment inks in collaboration with Durst Phototechnik AG, a company devoted to image processing, and Fujifilm Dimatix (Spectra), a printhead manufacturer (Sanz et al., 2012). Information from interviews shows that a range of different strategies was employed. These included experimenting with equipment developed by companies with experience in design and engineering of coupling printheads already on the market (KERAjet JETTABLE in Israel), collaborations and joint marketing strategies involving a manufacturer of frits, glazes and ceramic colours and a specialist in digital printing machines (TORRECID and DURST, using binary Fujifilm Dimatix heads), and a manufacturer of machines for ceramic decoration and a specialist in digital printing machines (CretaPrint and the Italian firm TENOITALIA with Xennia). In 2012, there are at least 13 different machines available in the market and the most widely used printheads are piezoelectric provided by Xaar, Spectra and Seiko.

'We should not forget that it is a very recent technology and it is understandable that it should be adopted by the most important firms before the other follow their example' ...' it would require a big change in production mentality' (VP, manufacturer).
The first Tecnargilia Design Award in 2010 to celebrate the latest technological innovation in this sector was for digital decoration. Tecnargilia is the most important international fair for technological and stylistic innovations for the ceramics industry. Figures 6 and 7 depict the progressive adoption of IJP technology. It shows the number of companies that have manufactured machines since 2000 and the number of machines installed in April 2010 ( $N=373$ machines) (Giacomini, 20 10). The number of machines in April 20II was 664, $48.6 \%$ of which are Spanish in origin and $31 \%$ are Italian.

From 2000 to 2008, with the exception of JETTABLE which developed its own inks, tile firms were supplied exclusively by KERAjet-Ferro and Torrecid-Durst. This probably slowed the introduction of IJP technology in the sector. In 2009, KERAjet-Ferro and Torrecid-Durst began to supply inks from other certified sources. KERAjet developed a certification protocol for testing and control of ink quality and currently has a presence in several major ceramics centres in Spain, Italy, Portugal, China, and other countries. Through continuing investment in knowledge and accumulated competences the firm has produced several generations of machines. In Spain, and particularly in the CCDIS and the construction industry on which it depends, the economic downturn has had a major effect on tile manufacture. However, in $2010 \mathrm{KE}-$ RAJet SA had 200 machines installed and functioning across the world, which is evidence of the success of IJP technology in the ceramics field.

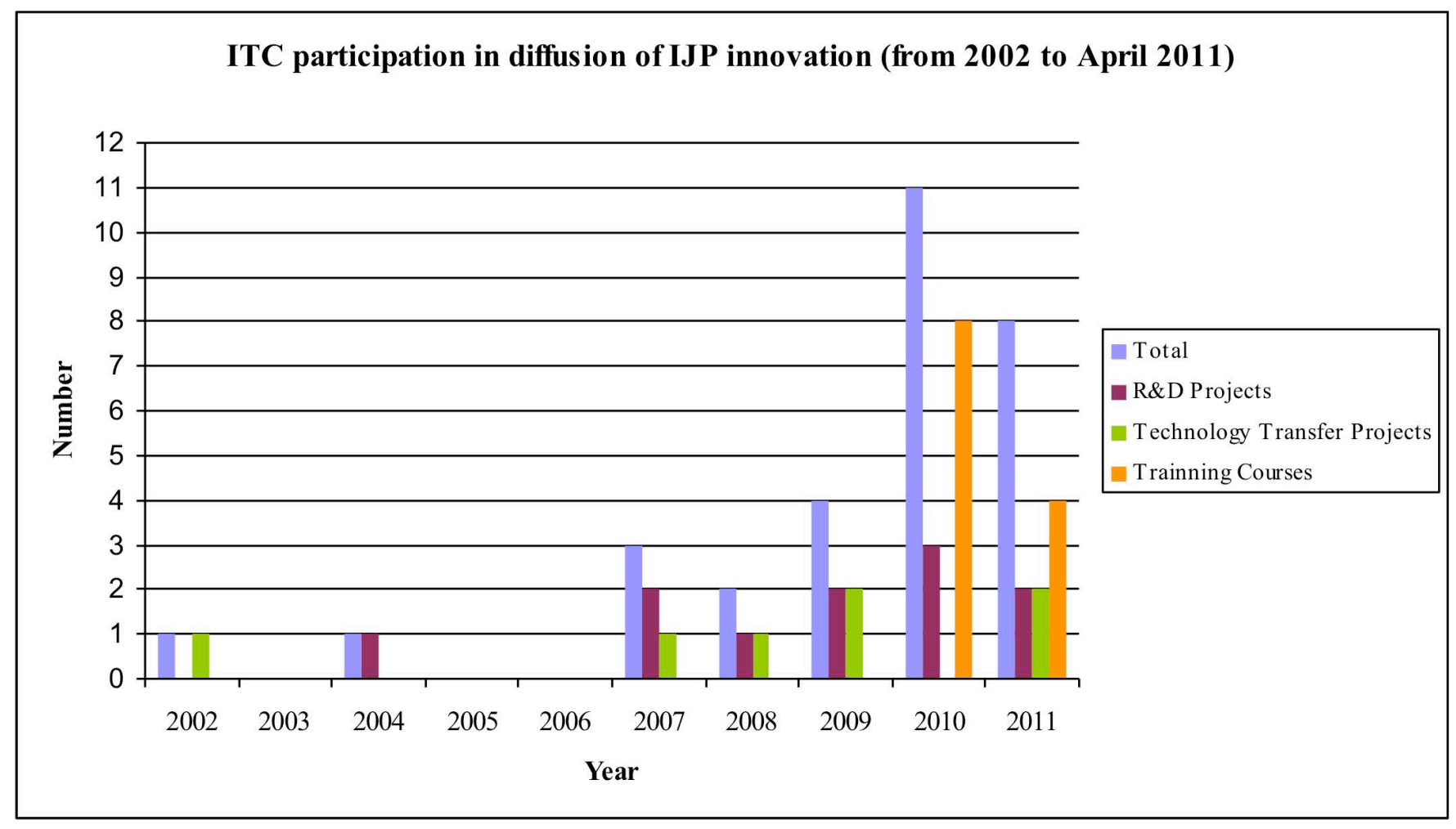

Figure 7.Activities developed in cooperation between firms and ITC related to IJP technology

ISSN: 07 I8-2724. (http://www.jotmi.org)

Journal of Technology Management \& Innovation (c) Universidad Alberto Hurtado, Facultad de Economía y Negocios. 
According to Molina-Morales et al. (2002) the ITC acts as an intermediary bridging to external knowledge and new technologies and supports exploration and exploitation activity. However, our case study shows that the ITC did not participate in the exploration and R\&D stages, but played a key role in the diffusion of and further improvement to IJP technology. Figure 7 depicts the formation activities, technology transfer and R\&D joint projects developed by firms in cooperation with the ITC. Table I summarizes several aspects related to the process of innovation and especially the non-linearity of the knowledge flows.

\section{Conclusion and final comments}

This paper investigated an innovation process in a Spanish region introducing an analytical approach (DIS) that combines theoretical perspectives of RIS, IDs and Innovation Systems. We describe the introduction and progress of the IJP technology at micro-level, analyzing this innovation from the evolutionary point of view including the starting point, interactions and feedback involved in its generation during all the innovation process. Although the IJP technology does not constitute a radical innovation (it only involves some of the value chain in the ceramic production), it can be described as a very 'relevant innovation' related to ceramic decoration that is revitalizing the ceramic sector. Our indepth case study shows that the IJP technology emerged as a result of local dynamic interactions in the CCDIS and also it represented a break in the pattern of ceramic machinery innovations originating in Italy. Both external and internal links were crucial for the development, confirming previous findings related to heterogeneity in the ceramic district from a micro-level perspective (Molina-Morales and MartínezFernández, 2009a). Informal relationships related to cooperation and information exchanges underpinned by mutual trust and face-to-face contacts and the role of in-house R\&D in the innovation process, particularly due to the frit, glaze and colour providers were determinants for this innovation (Tortajada et al., 2008; Gabaldón et al., 2009). One of the most remarkable aspects is the importance of external ties and relationships with foreign firms, aspects that are generally neglected by mainstream studies of ID. The development of IJP technology within the CCDIS can be characterized as result of a 'learning system' where the act of building external linkages and complementing internal knowledge with external knowledge (e.g. with the Cambridge 'district', the external suppliers Xaar and Seiko, the Drupa fair, etc.) was crucial. The venture team -an entrepreneur of a small firm and their friends, one of them from a multinational subsidiary- participated in an evolving and recursive process of exploration and absorption of external knowledge from other industry sectors. This collaboration was based on a common culture of trust and mutual reinforcing capabilities and provided informational and other benefits related to access, timing and referrals, in a competitive environment marked by trust and secrecy communicative strategies. In this sense

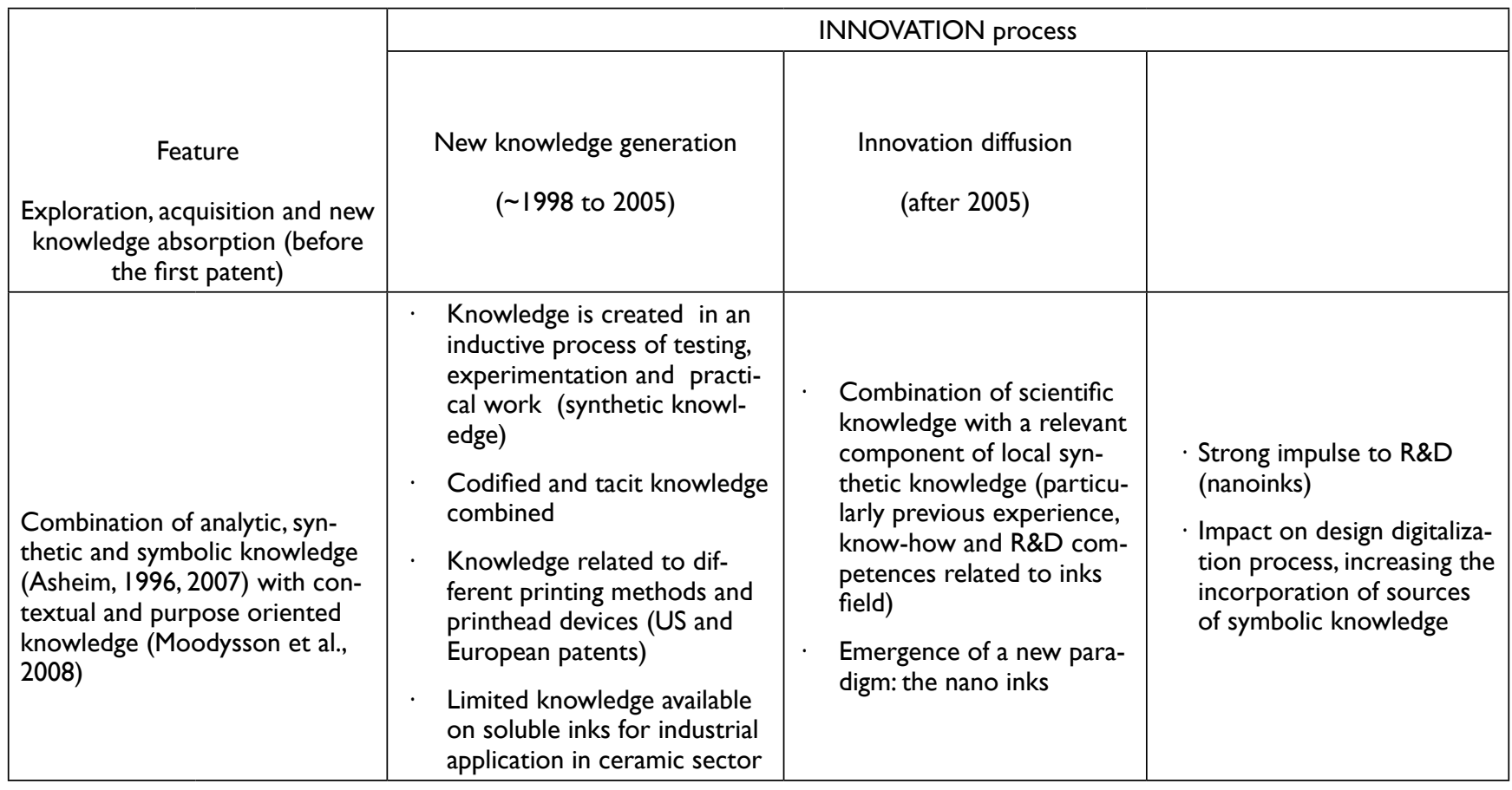

ISSN: 07 I8-2724. (http://www.jotmi.org) 


\begin{tabular}{|c|c|c|c|c|}
\hline \multirow[t]{2}{*}{$\begin{array}{l}\text { Sources of } \\
\text { knowledge } \\
\text { and relevant } \\
\text { actors }\end{array}$} & $\begin{array}{l}\text { Internal net- } \\
\text { works (links } \\
\text { in the CCDIS } \\
\text { structure and } \\
\text { with the local } \\
\text { environment) }\end{array}$ & $\begin{array}{l}\text { Developers of the first IJP } \\
\text { machine: JVTC (electronic } \\
\text { engineer) director of a small } \\
\text { enterprise supplier of soft- } \\
\text { ware and electronic applica- } \\
\text { tions for ceramic industry } \\
\text { (Enginyeria PC), his partner } \\
\text { RV (industry engineer) and } \\
\text { AQ (chemistry degree) from } \\
\text { Ferro Enamel Spain S.A. } \\
\text { R\&D process begin with } \\
\text { informal contacts between a } \\
\text { small supplier firm and a Fer- } \\
\text { ro, in the 'core' knowledge of } \\
\text { the Frit and Glaze Subsector } \\
\text { Other attempts to adapt } \\
\text { printheads for industry ce- } \\
\text { ramic }\end{array}$ & $\begin{array}{l}\text { I998 Start R\&D in adap- } \\
\text { tation of printheads and } \\
\text { inks proofs (trial an error } \\
\text { method) } \\
\text { Joint venture constitution: } \\
\text { KERAjet (spin-off of Ferro } \\
\text { Enamel Spain S.A.) } \\
2000 \text { First prototype pre- } \\
\text { sentation at CEVISAMA } \\
2000 \text { Development of two } \\
\text { new prototypes and Ferro } \\
\text { began producing a range } \\
\text { of CMYK (Cyan, Magenta, } \\
\text { Yellow, Black) colour inks } \\
\text { in solution } \\
\text { ( 2000) Other firms } \\
\text { intended simoultaneously } \\
\text { to develop inks } \\
2001 \text { Start commercializa- } \\
\text { tion } \\
2002 \text { Presentation of the } \\
\text { Kerajet K560 Model and } \\
\text { new inks } \\
2004 \text { to } 2008 \text { R\&D agree- } \\
\text { ment and technology } \\
\text { transfer with Seiko (print- } \\
\text { heads supplier) } \\
2004 \text { Presentation of } \\
\text { KERAjet k700 Model }\end{array}$ & $\begin{array}{l}\text { Consolidation of the KER- } \\
\text { Ajet start-up } \\
\text { - Development of several } \\
\text { Doctoral thesis related to } \\
\text { inks properties (Jaume I } \\
\text { University and ITC, Uni- } \\
\text { versity of Valencia) } \\
\text { - Links with universities and } \\
\text { public research institutions } \\
\text { (R\&D projects; seminars, } \\
\text { etc.) } \\
\text { - Leader participation of } \\
\text { ITC in elaboration of } \\
\text { reports on state-of-the- } \\
\text { art, R\&D and technology } \\
\text { transfer projects (e.g. } \\
\text { In } 20 \text { I I the Technology } \\
\text { Observatory published a } \\
\text { study entitled 'Ceramic } \\
\text { Decoration by IJP technol- } \\
\text { ogy' and also disseminated } \\
\text { the contents of this study } \\
\text { among companies). }\end{array}$ \\
\hline & $\begin{array}{l}\text { External net- } \\
\text { works }\end{array}$ & $\begin{array}{l}\text { Visit to international printing } \\
\text { fairs (DRUPA) } \\
\text { Trial and error activities with } \\
\text { plotters and intents of the } \\
\text { method of single-pass (other } \\
\text { firm in France) } \\
\text { Contacts with consultants of } \\
\text { the Cambridge printing clus- } \\
\text { ter (the principal influence at } \\
\text { CCDIS in this issue), particu- } \\
\text { larly the prinbtheads supplier } \\
\text { firm Xaar } \\
\text { Initial contacts with print- } \\
\text { heads suppliers: Xaar (United } \\
\text { Kingdom) and Seiko (Japan) }\end{array}$ & $\begin{array}{l}\text { Contacts with suppliers, } \\
\text { particularly Xaar (UK) } \\
\text { and Seiko (Japan) } \\
\text { R\&D and development of } \\
\text { other prototypes based } \\
\text { in other IJP technologies } \\
\text { in other countries (Italy, } \\
\text { Israel, Germany). }\end{array}$ & $\begin{array}{l}\text { - Intensification of relation- } \\
\text { ships with suppliers } \\
\text { - Began commercialization } \\
\text { of other firms. The first } \\
\text { Durst digital decoration } \\
\text { system with ceramic pig- } \\
\text { mented inks were tested } \\
\text { in Spain in January } 2005 \\
\text { and installed in Italy in July } \\
2006 . \\
\text { Intensification of KERAjet } \\
\text { exportation in the world } \\
\text { and creation of KERAjet } \\
\text { branches in Italy Portugal, } \\
\text { China and SouthAmerica } \\
\text { Emergence of inkjet print- } \\
\text { ing as a subsector? (it } \\
\text { represents around } 6 \% \text { of } \\
\text { exportation income) } \\
\text {. } 48.6 \% \text { of the machines } \\
\text { installed worldwide are } \\
\text { of Spanish origin and } 31 \% \\
\text { Italian one }\end{array}$ \\
\hline
\end{tabular}

ISSN: 07 I8-2724. (http://www.jotmi.org) 


\begin{tabular}{|c|c|c|c|}
\hline Cooperation with other agents & $\begin{array}{l}\text { Trusting cooperation at indi- } \\
\text { vidual level and inter-firm } \\
\text { Non-cooperation with uni- } \\
\text { versities and other research } \\
\text { organizations (ITC) } \\
\text { Non-cooperation with the } \\
\text { rest of agents at the CCDIS }\end{array}$ & \multicolumn{2}{|c|}{$\begin{array}{l}\text { Cooperation began after the presentation in CEVISAMA of } \\
\text { the first prototype (2000): Inter-firm, ITC, with other re- } \\
\text { search institutions and universities within and outside of the } \\
\text { CCDIS (e.g., in } 2007 \text { KERAjet and the Italian firm System Spa } \\
\text { developed the Rotojet Kit) } \\
\text { - Cooperation is the strategy followed by KERAjet with di- } \\
\text { verse local and external agents: firms such as Ferro, Xaar } \\
\text { (UK), System Spa (Italy, 2007), Seiko (Japan, 2004-2008); uni- } \\
\text { versities (Jaume I, Universidad Autónoma de Madrid in 2005); } \\
\text { with financial actors, etc. }\end{array}$} \\
\hline Cost \& Funding & $\begin{array}{l}\text { Internal } \\
\text { High costs due the materials } \\
\text { for inks experimentation } \\
\text { High uncertainty regarding } \\
\text { the R\&D advances and pos- } \\
\text { sibilities of industrial imple- } \\
\text { mentation }\end{array}$ & $\begin{array}{l}\text { - High initial financial support } \\
\text { from Ferro Enamel Spain } \\
\text { S.A. } \\
\cdot \text { I } 999 \text { CDTI support for } \\
\text { R\&D projects } \\
\text { - IMPIVA support for several } \\
\text { R\&D projects } \\
\text { - Strong effort in R\&D in- } \\
\text { house of KERAjet }\end{array}$ & $\begin{array}{l}\text { Government support for } \\
\text { building part of KERAjet } \\
\text { industrial installations } \\
\text { Public funding of R\&D } \\
\text { projects } \\
\text { In } 20 \text { II KERAjet has } 45 \\
\text { employees ( } 34 \% \text { of staff } \\
\text { realize R\&D activities) }\end{array}$ \\
\hline Knowledge protection & $\begin{array}{l}\text { High confidence, trust and } \\
\text { reciprocity } \\
\text { High secrecy in the initial de- } \\
\text { velopment and competition } \\
\text { with other firms within and } \\
\text { outside CCDIS }\end{array}$ & $\begin{array}{l}\text { The second patent (inks) } \\
\text { was a defensive one } \\
\text { - Confidentiality agreement } \\
\text { - High knowledge protection } \\
\text { (monopolistic in the inks } \\
\text { development) }\end{array}$ & $\begin{array}{l}\text { Change in knowledge } \\
\text { protection strategy of } \\
\text { KERAjet in } 2008 \text { (inks } \\
\text { quality certification) }\end{array}$ \\
\hline Human capital, competences & $\begin{array}{l}\text { High level of local technical skills, } \\
\text { knowledge and experience in inks } \\
\text { development applied to ceramic } \\
\text { sector }\end{array}$ & $\begin{array}{l}\text { Capabilities complementar- } \\
\text { ity between KERAjet and } \\
\text { Enginyeria PC }\end{array}$ & $\begin{array}{l}\text { New specific competenc- } \\
\text { es demand for the ceram- } \\
\text { ic sectorITC leaders the } \\
\text { offer of specific training } \\
\text { courses } \\
\text { Cooperation between } \\
\text { Kerajet and Colorobbia in } \\
\text { the first training programs }\end{array}$ \\
\hline Principal obstacles & $\begin{array}{l}\text { Knowledge barriers related to } \\
\text { the emergence of new paradigm } \\
\text { in inks research and development } \\
\text { (from micro to nano-inks) }\end{array}$ & $\begin{array}{l}\text { Problems related to the } \\
\text { stability and low chromatic } \\
\text { intensity of the inks for } \\
\text { application in an industrial } \\
\text { process } \\
\text { - High costs \& risk } \\
\text { - Demand of new specific } \\
\text { skills is seen as a limitation } \\
\text { for troducing IJP technology } \\
\text { - Strong 'traditional' cultural } \\
\text { environment }\end{array}$ & $\begin{array}{l}\text { Inks limitations (optimi- } \\
\text { sation of the chromatic } \\
\text { quality, improvement of } \\
\text { properties stability, reduc- } \\
\text { tion of production costs, } \\
\text { etc.) } \\
\text { R\&D high costs } \\
\text { Firms need 'change' their } \\
\text { mind about the new dec- } \\
\text { oration trends } \\
\text { Risk of homogeneity } \\
\text { trends in design } \\
\text { Impact of economic and } \\
\text { financial crisis. However, } \\
\text { according to Giacomini } \\
\text { (20I0, 20I I) the area of } \\
\text { ink-jet digital decoration } \\
\text { has continued to receive } \\
\text { investment during the } \\
\text { recent years of stagnation } \\
\text { in the ceramic sector }\end{array}$ \\
\hline
\end{tabular}

Table 3. Summary of results of case study

ISSN: 07I 8-2724. (http://www.jotmi.org)

Journal of Technology Management \& Innovation (c) Universidad Alberto Hurtado, Facultad de Economía y Negocios. 
this research illustrated that teams with greater strategic consensus can harvest greater benefits from appropriately structured external networks. Most of the knowledge to develop inks was tacit and rooted in practice in the frit subsector, as a combination of scientific knowledge and strong know-how (procedural knowledge rather than declarative knowledge). Other relevant factor was the long experience of skilled workers in whom the knowledge was 'embedded' and influenced by social ties, friendship, trust, reputation, solidarity, norms, habits and co-evolved rules of conduct. Trust relations enabled mechanisms to reduce inter-firm transaction costs and to complement managerial and technological capabilities, encompassing a complex process of interrelationships of endogenous (knowledge feedback) and exogenous (knowledge inputs) mechanisms in the learning district system. Secrecy and patenting also played a key role in the sharing of knowledge and innovation strategy, in particular related to the search for exploitation opportunities.

In contrast to previous literature, our case study shows that research institutions (the ITC and universities) did not act as an intermediate agent in the early exploration and R\&D stages (Molina-Morales et al., 2002), which explains that the IJP innovation emerge as 'different' or with certain degree of radicalness, by contrast with the incremental innovation in this industrial sector. However, the ITC together other research institutions like the University Jaume I participated in the diffusion of and improvements to IJP technology through collaborative R\&D projects with IMPIVA and CDTI. In particular, the ITC had a leading role providing courses and formation activities to ceramic technicians and engineers and also in projects for improving and disseminating this technology at both national and international levels.

This paper contributes by providing novel micro-empirical evidence for a better understanding of the complex dynamics in the sharing of knowledge during innovation processes beyond the traditional economic perspectives of 'industrial clustering' and ID. The paper's findings are limited in first place by the analytical focus on a single technology development and, in second place, for the impossibility to include information due the confidentiality agreement with some of the interviewees. This approach could be complemented by and extended with further studies.

\section{Acknowledgements}

This work was supported by ITC-AICE and the Quevedo Program of the Spanish Ministry of Science and Innovation Education and Culture through Project no. PB97-0804, and by the Agencia Española de Cooperación Internacional through the Project RedINNOVA 


\section{References}

ASHEIM, B.T. (1996). Industrial districts as 'learning regions': a condition for prosperity, European Planning Studies, 4, 379-400. DOI: I0.1080/096543 | 9608720354

ASHEIM, B. (2007). Differentiated knowledge bases and varieties of regional innovation systems, Innovation: The European Journal of Social Science Research 20(3), 223-24I. DOI:10.1080/13511610701722846

BARBA, A. (2005). From Chemical Engineering to ceramic technology: A review of research at the Instituto de Tecnología Cerámica, Boletín de la Sociedad Española de Cerámica y Vidrio, 44(3), I55- 160.

BECATTINI, G. (1990). The Marshallian Industrial District as a Socio-economic Notion. In F. Pyke F., Becattini G. and Sengenberger, W. (Eds.), Industrial Districts and Inter-firm Cooperation in Italy, International Institute for Labour Studies, Geneva.

BECATTINI, G.; Bellandi, M.; De Propis, L. (Eds.), (2009). A Handbook of Industrial Districts. Edward Elgar Pub., UK, USA.

BELUSSI, F.; Asheim, B. T. (20I0). Industrial Districts and Globalisation: Learning and Innovation in Local and Global Production and Innovation Systems. In Belussi, F. and A. Sammarra (Eds.), Business Networks in Clusters and Industrial Districts: the Governance of the global value chain. Routledge, London, 246-265.

BELUSSI, F. (1996). Local systems, industrial districts and institutional networks: towards a new evolutionary paradigm of industrial economics? European Planning Studies, 4(I), 5-26. DOI: |0.1080/096543/9608720326

BERTO A. M. (2007). Ceramic tiles: above and beyond traditional applications, J. European Ceram. Soc., 27,1607-1613. DOI: 10.1016/j.jeurceramsoc.

BOIX, R. (2009). The empirical relevance of industrial districts in Spain. In Becattini, G.; Bellandi, M. and De Propis, L. (Eds.).A Handbook of Industrial Districts. Edward Elgar Pub., UK, USA. Chap. 26, 343-359.

BOIX, R.; Galletto, V. (2006). Sistemas locales de trabajo y distritos industriales marshallianos en España. Economía Industrial, 359, I65-184.

BRAUNERHJELM, P.; Feldman, M. (2006). Cluster genesis. Technology-based industrial development. Oxford University Press, Oxford, UK.
BRESCHI, S.; Lissoni, F. (2004). Knowledge networks from patent data: methodological issues and research targets.WP $N^{\circ}$ 150. CESPRI.

BRUSCO, S. (1990). The idea of the industrial ditrict. Its genesis. In Pyke, F.; Becattini, G. and Sengenberger,W. (Eds.), Industrial Districts and Local Economic Regeneration. International Institute for Labor Studies, Geneva, 10-19.

BUESA, M.; Heijs, J.; Martínez-Pelletero, M.; Baumert, T. (2005). Regional systems of innovation and the knowledge production function: the Spanish case. Technovation, 26, 436472. DOI: 10.1016/j.technovation.2004.11.007

BUESA, M.; Heijs, J. (coords.) (2007). Sistemas regionales de innovación: Nuevas formas de análisis y medición. Ed. Fundación de las Cajas de Ahorro, Madrid, España.

CANIËLS M.C.J.; Romijn H.A. (2003). Firm-level knowledge accumulation and regional dynamics, Industrial and Corporate Change, I2(6), I253-I278. DOI: I0.1093/icc/ 2.6. I253

CANTNER, U.; Meder, A.; Ter Wal, A. L. J. (20I0). Innovator networks and regional knowledge base, Technovation 30, 496-507. DOI: 10.1016/j.technovation.2010.04.002

COHEN, W. M.; Levinthal, D. A. (1990). Absorptive Capacity: A New Perspective on Learning and Innovation, Admin. Sci. Quart., 35 (I), I28-I 52.

CLYMER, N.; Asaba, S. (2008). A new approach for understanding dominant design: the case of the ink-jet printer, Journal of Engineering Technology Management, 25, I 37-I 56. DOI: 10.1016/j.jengtecman.2008.06.003

COOKE, P. (1996). Reinventing the region: firms, clusters and networks in economic development. In Daniels \& Lever (Eds.), The global economy in Transition. Longman, Essex, UK.

COOKE, P. (200I). Regional innovation systems, clusters, and the knowledge economy, Industrial and Corporate Change, I0(4), 945-974. DOI: I0.1093/icc/ 10.4.945

COOKE, P. (2005). Regionally asymmetric knowledge capabilities and open innovation. Exploring "Globalisation 2". A new model of industry organisation, Research Policy, 34, | | 28-I | 49. DOI: 10.10 |6/j.respol.2004.12.005

COOKE, P. (2009). Technology clusters, industrial districts and regional innovation systems. In Becattini, G.; Bellandi, M. \& De Propis, L. (Eds.). A Handbook of Industrial Districts. Edward Elgar Pub., UK, USA. Chap. 23, pp. 295-342. 
COOKE, P.; Morgan, K. (1993). The network paradigm: new departures in corporate and regional development, Environment and Planning D: Society and Space, I I (5), 543-564.

COOMBS, R., Harvey, M.; Tether, B. (2003). Analysing distributed processes of provision and innovation, Industrial and Corporate Change, 12, 105I-108I. DOI: 10.1093/ icc/12.6.1 I 25

DAVENPORT, H. ; Prusak, L. (2000). Working Knowledge. Harvard Business School Press.

DE CARLO, A.; Montani, M. (2003). The digital revolution in tile decoration, Ceramic World Review, 5I,78-84.

DOLOREUX, D. (2002). What we should know about regional systems of innovation, Technology in Society, 24(3), 243-263. DOI: 10.1016/S0160-791X(02)00007-6

DOSI, G. (1982). Technological paradigm and technological trajectories, Research Policy, II(3), I47-I62. DOI: 10.1016/0048-7333(82)90016-6

EDQUIST, C. (Ed.). (1997). Systems of innovation: technologies, institutions and organizations. Pinter, London, UK.

EISENHARDT, K. M. (1989), 'Building Theories from Case Study Research', Academy of Management Review, (4), 532550. DOI: 10.5465/AMR. 1989.4308385

ESCARDINO, A. (200I). La innovación tecnológica en la industria cerámica de Castellón, Boletín de la Sociedad Española de Cerámica y Vidrio, 40(I), 43-5I.

EXPÓSITO-LANGA, M.; Molina-Morales, F. X. (2010). How Relational Dimensions Affect Knowledge Redundancy in Industrial Clusters, European Planning Studies, 18(I2), 19751992. DOI:10.1080/09654313.2010.515817

EVANGELISTA, R., lammarino, S.; Mastrostefano,V.; Silvani,A. (2002). Looking for regional systems of innovation. Evidence from the Italian innovation survey, Regional Studies, 36,(2), |73-|86. DOI: 10.1080/00343400220121963

FERRO Italia. (200I). Tile Decoration moves into the 2 I st century, a Digital Revolution:The story of Kerajet Technology, International Ceramics Journal. Product Technology.

FLORIDA, R. (1995). Toward the learning region, Futures, 27(5), 527-536. DOI: 10.1016/0016-3287(95)0002I-N
GARNSEY, E.; Stam, E.; Thomas, B. (2010). The emergence and development of the Cambridge ink jet printing industry. In Fornahl, D.; Henn, S. and Menzel, M. P. (Eds.). Emerging clusters. Theoretical, empirical and political perspectives on the initial stage of cluster evolution. Edward Elgar Pub., UK, USA., 265-29I.

GABALDÓN-ESTEVAN, D.; Molina-Morales, F. X.; Fernández-De-Lucio, I. (2009). Research contracts and patents in the Spanish ceramic tile district innovation system. INGENIO (CSIC-UPV). Working Papers Series 2009-I.

GEORGE, A. L.; Bennett, A. (2005). Case studies and theory development in the social sciences. MIT Press, Cambridge, MA.

GIACOMINI, P. (2010). A digital future? Ceramic World Review, 86, 56-75.

GIACOMINI, P. (20II). The unstoppable growth of digital technology, Ceramic World Review, 98, 48.

GORDON, I.; Mccann, P. (2000). Industrial clusters: complexes, agglomeration and/or social networks?, Urban studies, 37, 5I3-532. DOI: I0.1080/0042098002096

HARRISON, B. (1992). Industrial districts: old wine in new bottles?, Regional Studies, 26, 269-483. DOI: 10.1080/00343400701232264

HEIDENREICH, M. (2005). The renewal of regional capabilities. Experimental regionalism in Germany, Research Policy, 34, 739-757. DOI: I0.1016/j.respol.2005.04.004

HERRSCHEL, T. (20I0). Growth and Innovation of Competitive Regions: The Role of Internal and External Connections, European Planning Studies, 18(7), I169-1172. DOI: I0.1080/096543II0037442I I

HUTCHINGS, I.M. (2009). Ink-jet printing in micro-manufacturing: opportunities and limitations. In Proc. 4M/ICOMM Int. Conf. on Multi-material Micro Manufacture, Cardiff University: Karlsruhe, Germany.

IAMMARINO, S. (2005). An evolutionary integrated view of regional systems of innovation. Concepts, measures and historical perspectives, European Planning Studies, 13(4), 497519. DOI: I0.1080/09654310500107084

IAMMARINO, S.; Mccann, P. (2006). The structure and evolution of industrial clusters:Transactions, technology and knowledge spillovers, Research Policy, 35, 1018-1036. DOI: 10.1016/j.respol.2006.05.004 
JØRGENSEN, M.; Phillips, L. (2002). Discourse Analysis as Theory and Method. SAGE London, Thousand Oaks, New Delhi.

KEEBLE, D.; Wilkinson, F. (1999). Colective Learning and Knowledge development in the evolution of regional clusters of high technology SMEs in Europe, Regional Studies, 33(4): 295-303. DOI: I0.1080/0034340995008। I67

LORENZEN, M. (2005).Why do clusters change?, European Urban and Regional Studies, 12(3), 203-208.

LUNDVALL, B.A. (1992). National Systems of Innovation: towards a theory of innovation and interactive learning. Pinter, London, UK.

LUNDVALL, B. A. (2007). National Innovation Systems. Analytical concept and development tool, Industry and Innovation, I4(I), 95-I I 9. DOI: I 0. I080/ I 36627 I 060 I I 30863

LUNDVALL, B-Å.; Borras, S. (1997).The Globalising Learning Economy: Implications for Innovation Policy. European Communities, Luxembourg.

MALERBA, F. (2002). Sectoral systems of innovation and production, Research Policy, 31, 247-264. DOI: 10.1016/S00487333(0I)00I39-I

MALERBA, F. ; Vonortas, N. S. (Eds.). (2009), Innovation networks in industries. Edward Elgar Pub. UK, USA.

MEYER-STAMER, J. et al. (2004). Upgrading in the Tile Industry of Italy, Spain and Brazil: insights from cluster and value chain analysis. In: Schmitz, H. (Ed.). Local Enterprises in the Global Economy: Issues of Governance and Upgrading. Edward Elgar Pub., Cheltenham, UK.

MOLINA-MORALES, F.X. (2002), 'Industrial districts and innovation: the case of the Spanish ceramic tiles industry', Entrepreneurship and Regional Development, I4(4), 317-335.

MOLINA-MORALES, F.X.; Martínez-Fernández, M.T. (2009a). Does homogeneity exist within industrial districts? A social capital-based approach, Papers in Regional Science, 88(I), 209-229.

MOLINA-MORALES, F. X.; Martínez-Fernández, M. T. (2009b). Too much love in the neighborhood can hurt: how an excess of intensity and trust in relationships may produce negative effects on firms. Strategic Management Journal, 30, 1013-1023.
MOLINA-MORALES, F.X., López-Navarro, M.A.; Guia-Julve,J. (2002).The Role of Local Institutions as Intermediary Agents in the Industrial District, European Urban and Regional Studies, 9, 3 I5-329. DOI: 10.1 I77/096977640200900403

MOODYSSON, J., Coenen, J.; Asheim, B. (2008). Explaining spatial patterns of innovation: analytical and synthetic modes of knowledge creation in the Medicon Valley lifescience cluster, Environment and Planning 40, 1040-I056. DOI: I0.1068/ a39110

MORENO, A.; Lázaro, V.; Mateu, A.; Reig, Y. (20I0). Innovations and new trends in ceramic tile decoration, Advances in Science and Technology, 68, I65-175. DOI: 10.4028/www. scientific.net/AST.68.165

MOTOYAMA, Y. (2008). What Was New About the Cluster Theory?:What Could It Answer and What Could It Not Answer?, Economic Development Quarterly, 22,353-363. DOI: I0.1 I77/089|242408324373

MOULAERT, F; Sekia, F. (2003). Territorial innovation models: a critical survey, Regional Studies, 37, 289-302. DOI:10.1080/0034340032000065442

NELSON, R. R. (1995). Recent theorizing about economic change, Journal of Economic Literature 33(I), 48-90.

PORTER, M. and Ketels, C. (2009). Clusters and industrial districts: common roots, different perspectives. In Becattini, G.; Bellandi, M.; De Propis, L. (Eds.).A Handbook of Industrial Districts. Edward Elgar Pub., UK, USA, I72-183.

QUEROL VILLALBA,A.M.; Guaita Delgado, F.J., $\quad$ Ferro Spain S.A. (2002). Nueva tinta amarilla para la decoración de artículos de cerámica y vidrio mediante tecnología inkjet. Patent N ${ }^{\circ}$ ES2209634

SANZ,V.; Reig,Y.; Feliu, C.; Bautista,Y.; Ribes, C.; Edwards, M. (20I2). Technical Evolution of Ceramic Tile Printing. Journal of Imaging Science and Technology, 56, 40 I-407

SEONG-JIM K.; Mckean, D.E. (1998). Aqueous TiO2 suspension preparation and novel application of ink-jet printing technique for ceramics patterning, Journal of materials science letters, I7, I4I-I 44.

SFORZI, F. (2006). El distrito industrial y el 'viraje territorial' en el análisis del cambio económico, Economía Industrial. El distrito industrial marshalliano: un balance crítico de 25 años. Ministerio de Industria y Comercio de España. 359, $37-42$. 
SOCIEDAD ESPAÑOLA DE CERÁMICA Y VIDRIO (20I0). Innovación y desarrollo del azulejo en las tres últimas décadas: colección de los premios Alfa de Oro 1977-2009. Madrid.

STORPER, M. (1993). Regional 'Worlds' of Production: Learning and Innovation in the Technology Districts of France, Italy and the USA, Regional Studies, 27(5), 433-455. DOI: 10.10 80/003434093 | 233 |347675

STORPER, M. (1997). The regional world: territorial development in a global economy. Guilford Press, London, UK.

TOMÁS CLARAMONTE, J.V. (1999). Dispositivo para decorar baldosas cerámicas. Patent Nº EP99949020.4.

TORTAJADA ESPARZA, E.; Fernández de Lucio, l.; Gabaldón Estevan, D. (2008). Competitiveness and Profitability? New Challenges in the Ceramic Frit, Glaze and Colour Industry, Tile \& Brick International. Manual 2008:59-65.

VONORTAS, N. S. (2009). Innovation networks in industry. In Malerba, F. \& Vonortas, N. S. (Eds.). Innovation networks in industries. Edward Elgar Pub. UK, USA, 27-44.

WIJSHOFF, H. (2008). Sructure and fluid-dynamics in piezo inkjet printheads. Herman Wijshoff.Venlo, The Netherlands.

YBARRA, J. A. (1991). Industrial districts and the Valencian Community. New industrial organisation programme. Discussion Papers DP/44 (Geneva: International Institute for Labour Studies).

ZIRULIA, L. (2009). The dynamics of networks and the evolution of industries: a survey of empirical literature. In Malerba, F. \& Vonortas, N. S. (Eds.). (2009). Innovation networks in industries. Edward Elgar Pub. UK, USA, 45-77. 
Appendix - Tables I and 2.

\begin{tabular}{|c|c|c|c|c|c|c|}
\hline Inventor/author & $\begin{array}{l}\text { Firm/organiza- } \\
\text { tion }\end{array}$ & Patent/s article & $\begin{array}{l}\text { Pub. } \\
\text { date }\end{array}$ & Description & Pigment size & Ink type \\
\hline Anthony C.Airey & $\begin{array}{l}\text { British Ceram } \\
\text { Research Ltd. }\end{array}$ & GBI99I0004I7I & 1991 & $\begin{array}{l}\text { Ink jet printer ink for printing on } \\
\text { ceramics or glass }\end{array}$ & $\begin{array}{l}d_{50} 0.2-2 \\
\mu \mathrm{m}\end{array}$ & Aqueous \\
\hline Sherry A. & $\begin{array}{l}\text { General Electric } \\
\text { Company PLC }\end{array}$ & WO985I749 & 1997 & $\begin{array}{l}\text { Sedimentation free jet ink com- } \\
\text { position }\end{array}$ & $d_{50}<50 \mathrm{~nm}$ & $\begin{array}{l}\text { Termoplástica } \\
\text { Cambio de } \\
\text { fase (solvente } \\
\text { orgánico) }\end{array}$ \\
\hline $\begin{array}{l}\text { Seong-Jin Kin; } \\
\text { P.E. MCkean }\end{array}$ & $\begin{array}{l}\text { Samsung } \\
\text { IBM }\end{array}$ & Article & 1998 & $\begin{array}{l}\text { Aqueous TiO2 suspension prepa- } \\
\text { ration and novel application of } \\
\text { ink-jet printing technique for } \\
\text { ceramics patterning. Journal of } \\
\text { materials science letters Vol. I7, } \\
\text { |4|-|44. }\end{array}$ & $\mathrm{TiO} 2-50 \mathrm{~nm}$ & Aqueous \\
\hline Oishi Tomohiro & $\begin{array}{l}\text { Gifu Seramikussu } \\
\text { Gifutsu }\end{array}$ & JP200I08I363 & 1999 & $\begin{array}{l}\text { Color ink for inkjet printers has } \\
\text { inorganic pigment or mixture of } \\
\text { inorganic pigment and glass frit, } \\
\text { of smaller particle diameter, and } \\
\text { dispersing agent with inhibits } \\
\text { precipitation of inorganic pig- } \\
\text { ment or glass frit. }\end{array}$ & $d_{50} 0.3-2 \mu \mathrm{m}$ & Aqueous \\
\hline $\begin{array}{l}\text { Pfaff , P. Ragnetti } \\
\text { M. }\end{array}$ & Degussa & DEI9991021925 & 1999 & $\begin{array}{l}\text { (In)direct ink-jet printing of de- } \\
\text { cor on solid, especially fireproof } \\
\text { materials, e.g. glass, ceramics, } \\
\text { enamel or metal, uses paste with } \\
\text { high inorganic content and mol- } \\
\text { ten thermoplastic medium and } \\
\text { heated ink-jet head }\end{array}$ & --- & $\begin{array}{l}\text { Termoplástico } \\
\text { Cambio de } \\
\text { fase a } 45^{\circ}-60^{\circ}\end{array}$ \\
\hline $\begin{array}{l}\text { Sereni; Juncosa; } \\
\text { Jovaní }\end{array}$ & $\begin{array}{l}\text { Colorobbia Es- } \\
\text { paña }\end{array}$ & ES2I 70667 & 2000 & $\begin{array}{l}\text { Photosensitive ink for ceramics } \\
\text { ink jet decoration, consists of } \\
\text { inorganic temperature resistant } \\
\text { fraction and an organic fraction } \\
\text { also containing photo initiator(s) } \\
\text { and photosensitive components. }\end{array}$ & $\begin{array}{l}d_{100}<10 \mu \mathrm{m} \\
d_{50}<1 \mu \mathrm{m}\end{array}$ & $\begin{array}{l}\text { Reactivo } \\
\text { (fotosensible } \\
\text { +fotoini- } \\
\text { ciador) }\end{array}$ \\
\hline $\begin{array}{l}\text { Murota Masa- } \\
\text { michi; Shirono } \\
\text { Hirokuni;Arai } \\
\text { Masahide }\end{array}$ & Degussa AG & JP20000200794 & 2000 & $\begin{array}{l}\text { Aqueous nanoparticle ceramic } \\
\text { agglomerate dispersion for form- } \\
\text { ing ink-absorbing layer of ink-jet } \\
\text { recording medium. }\end{array}$ & $\begin{array}{l}d_{50} 0.05-0.3 \\
\mu \mathrm{m}\end{array}$ & Aqueous \\
\hline $\begin{array}{l}\text { Doyle J; Megher, } \\
\text { P }\end{array}$ & $\begin{array}{l}\text { Carey Brothers } \\
\text { Limited }\end{array}$ & EPI22320I & 2001 & $\begin{array}{l}\text { Ink, for ink jet printing method } \\
\text { including firing to fuse ink to } \\
\text { substrate, comprises carrier } \\
\text { material, having melting point for } \\
\text { phase change of ink, pigment; and } \\
\text { fusible vitreous agent. }\end{array}$ & $\begin{array}{l}\mathrm{D}_{100}<10 \mu \mathrm{m} \\
\text { preferible- } \\
\text { mente } 5 \mu \mathrm{m}\end{array}$ & $\begin{array}{l}\text { Termoplástico } \\
\text { Cambio de } \\
\text { fase a } 50^{\circ}\end{array}$ \\
\hline $\begin{array}{l}\text { Querol Villalba, } \\
\text { A.M.. Guaita } \\
\text { Delgado, F.J, }\end{array}$ & Ferro Spain SA & ES2209634 & 2002 & $\begin{array}{l}\text { Nueva tinta amarilla para la dec- } \\
\text { oración de artículos de cerámica } \\
\text { y vidrio mediante tecnología } \\
\text { inkjet (Translation: New ywllow } \\
\text { ink for decorating ceramic and } \\
\text { glass with ink-jet technology) }\end{array}$ & $\begin{array}{l}\mathrm{TiO}_{2} \text { coloidal } \\
\mathrm{d}_{100}<0.1 \mu \mathrm{m} \\
\text { preferible- } \\
\text { mente } \mathrm{d}_{100}< \\
0.05 \mu \mathrm{m}\end{array}$ & $\begin{array}{l}\text { Non Aqueous } \\
\text { (disolvente } \\
\text { alifático) }\end{array}$ \\
\hline
\end{tabular}

ISSN: 07 I8-2724. (http://www.jotmi.org) 


\begin{tabular}{|c|c|c|c|c|c|c|}
\hline $\begin{array}{l}\text { Bishop P; Dal- } \\
\text { ton, J. }\end{array}$ & $\begin{array}{l}\text { Johnson Mattey } \\
\text { PLC }\end{array}$ & WO200505207I & 2003 & $\begin{array}{l}\text { Digital printing ink composition } \\
\text { useful for coatings substrates, } \\
\text { e.g. ceramic comprises particles } \\
\text { glass frit of metal and dispersion } \\
\text { medium }\end{array}$ & $\begin{array}{l}d_{100}<2 \mu \mathrm{m} \\
d_{50}<0.7 \mu \mathrm{m}\end{array}$ & Aqueous \\
\hline $\begin{array}{l}\text { Corts Ripoli, J.V; } \\
\text { Sanmiguel Ro- } \\
\text { che, F.; Concep- } \\
\text { ción Heydorn, C. }\end{array}$ & Torrecid S.A. & WO2006077273 & 2005 & Industrial decoration ink & $d_{100}<3 \mu \mathrm{m}$ & Non Aqueous \\
\hline $\begin{array}{l}\text { Green;Warren; } \\
\text { Pele Dh }\end{array}$ & Jettable & WO2006126189 & 2005 & $\begin{array}{l}\text { Pigmented ink useful in drop- } \\
\text { on-demand inkjet printing for } \\
\text { decorating ceramic comprises } \\
\text { pigment of specific particle size, } \\
\text { a dispersant and a medium ex- } \\
\text { hibiting specific surface tension }\end{array}$ & $d_{50}<I \mu \mathrm{m}$ & Non Aqueous \\
\hline $\begin{array}{l}\text { Kimura } \\
\text { Takashori; Endo- } \\
\text { hiroki }\end{array}$ & Nippon Amu KK & JP2007084623 & 2005 & $\begin{array}{l}\text { Ink for ink-jet printer, contains } \\
\text { solvent, dispersing agent, and } \\
\text { inorganic pigment having pres- } \\
\text { ent median size and particles of } \\
\text { present diameter. }\end{array}$ & $\begin{array}{l}d_{50} 0.8-1.7 \\
\mu \mathrm{m}\end{array}$ & Non Aqueous \\
\hline $\begin{array}{l}\text { Querol A.M.; } \\
\text { Guiata F. }\end{array}$ & Ferro Spain SA & ES2289916 & 2006 & $\begin{array}{l}\text { Dispersión coloidal de pigmen- } \\
\text { tos cerámicos (Ceramic pig- } \\
\text { ments colloidal dispersion). }\end{array}$ & $d_{50} 0.3-2 \mu \mathrm{m}$ & Non Aqueous \\
\hline Yokoyama Ohata & $\begin{array}{l}\text { Gifu Seramikussu } \\
\text { Gifutsu }\end{array}$ & JP2007238400 & 2006 & $\begin{array}{l}\text { Marking method of industrial } \\
\text { commodity e.g. ceramic prod- } \\
\text { ucts, involves preparing ink by } \\
\text { adding specific amount of dis- } \\
\text { persing agent with respect to in- } \\
\text { organic pigment and performing } \\
\text { inkjet printing to mark ceramic } \\
\text { structure. }\end{array}$ & ---- & Non Aqueous \\
\hline $\begin{array}{l}\text { Dondi; Mat- } \\
\text { teucci; } \\
\text { Gardini }\end{array}$ & $\begin{array}{l}\text { CNR - ISTEC } \\
\text { CERICOL }\end{array}$ & $\begin{array}{l}\text { Working Docu- } \\
\text { ment }\end{array}$ & 2006 & $\begin{array}{l}\text { Industrial ink-jet application of } \\
\text { nano-sized ceramic inks. TTP }\end{array}$ & $d_{90} 10-50 \mathrm{~nm}$ & Non Aqueous \\
\hline $\begin{array}{l}\text { Gardini D.; } \\
\text { Dondi M.; Costa } \\
\text { A.L.; Matteuchi F; } \\
\text { Blosi M.; Galassi } \\
\text { C.; Cinotti E. } \\
\end{array}$ & $\begin{array}{l}\text { CNR-ISTEC } \\
\text { CERICIL }\end{array}$ & Article & 2008 & $\begin{array}{l}\text { Nano-sized ceramic inks for } \\
\text { drop-on-demand ink-jet printing } \\
\text { in quadrichromy. J. Nanosci Nan- } \\
\text { otechnol.Vol. 8(4), 1979-88. }\end{array}$ & $d_{90} 10-40 \mathrm{~nm}$ & Non Aqueous \\
\hline $\begin{array}{l}\text { Cavalcante, PMT.; } \\
\text { Dondi, M.; Guari- } \\
\text { ni, G.; Raimondo, } \\
\text { M.; Balbi, G. }\end{array}$ & $\begin{array}{l}\text { Universidad } \\
\text { Federal do } \\
\text { Rio de Janeiro } \\
\text { - CNR-ISTEC - } \\
\text { CERICOL } \\
\end{array}$ & Article & 2009 & $\begin{array}{l}\text { Colour Performance of Ceramic } \\
\text { Nano-pigments. Dyes and Pig- } \\
\text { ments,Vol. 80, 226-232. }\end{array}$ & $d_{90} 10-40 \mathrm{~nm}$ & Non Aqueous \\
\hline $\begin{array}{l}\text { Obata, S.; Kato, } \\
\text { M.;Yokoyama H.; } \\
\text { Iwata,Y.; Kiku- } \\
\text { motoY. }\end{array}$ & $\begin{array}{l}\text { Gifu Seramikussu } \\
\text { Gifutsu Tajimi } \\
\text { City } \\
\text { Pottery Design } \\
\text { and Technical } \\
\text { Center } \\
\text { Faculty of En- } \\
\text { gineering, Gifu } \\
\text { University }\end{array}$ & Article & 2011 & $\begin{array}{l}\text { Syntesis of nano CoAl2O4 } \\
\text { pigment for ink-jet printing to } \\
\text { decorate porcelain. J. Ceram. Soc. } \\
\text { Jap.Vol. I I9 (I387), 208-2 I3. }\end{array}$ & $d_{50} 70 \mathrm{~nm}$ & Aqueous \\
\hline
\end{tabular}

Table I. Scientific articles, reports and patents on pigment inks for decorating ceramic

ISSN: 07I 8-2724. (http://www.jotmi.org)

Journal of Technology Management \& Innovation (c) Universidad Alberto Hurtado, Facultad de Economía y Negocios. 


\begin{tabular}{|c|c|c|c|}
\hline Titular & Inventors & Tittle/description & Priority date \\
\hline $\begin{array}{l}\text { Tomas Claramon- } \\
\text { te, J.V. }\end{array}$ & $\begin{array}{l}\text { Tomas Claramon- } \\
\text { te, J.V. }\end{array}$ & $\begin{array}{l}\text { Dispositivo para decoración de baldosas cerámicas (Translation: } \\
\text { Device for decorating ceramic tiles) }\end{array}$ & $14 / 10 / 1998$ \\
\hline $\begin{array}{l}\text { Hegedus G; Kocsis } \\
\text { A; Florian G. }\end{array}$ & $\begin{array}{l}\text { Hegedus G; Koc- } \\
\text { sis A; Florian G. }\end{array}$ & Liquid Dispensing Apparatus & 09/03/1998 \\
\hline $\begin{array}{l}\text { SACMI COOPER- } \\
\text { ATIVA MECCANI }\end{array}$ & $\begin{array}{l}\text { Ricci Claudio; } \\
\text { Acerbi Pierugo }\end{array}$ & Method and device for decorating ceramic tiles & $08 / 09 / 2004$ \\
\hline System Spa & Stefani Franco & An apparatus for decorating ceramic products & $07 / 02 / 2006$ \\
\hline KERAJET SA & $\begin{array}{l}\text { Tomas Clara- } \\
\text { monte, J.;Vicent } \\
\text { Abella, Rafael; } \\
\text { Gasso Arcas, } \\
\text { Pedro }\end{array}$ & $\begin{array}{l}\text { Modulo autónomo de impresión por chorro de tinta (Translation: } \\
\text { Inkjet printing autonomous device ) }\end{array}$ & $28 / 11 / 2006$ \\
\hline $\begin{array}{l}\text { GRUPPO BARBI- } \\
\text { ERI \& TAROZZI }\end{array}$ & Tarozzi Fausto & Decoration method and system for decorating ceramic products & I7/04/2007 \\
\hline $\begin{array}{l}\text { XENNIA TECH- } \\
\text { NOLOGY LTD }\end{array}$ & $\begin{array}{l}\text { Yeong Kay K ; } \\
\text { Hirt Thomas }\end{array}$ & $\begin{array}{l}\text { Method, printing device, and formulations for decorating glass or } \\
\text { ceramic items }\end{array}$ & $19 / 02 / 2007$ \\
\hline CRETA PRINT, S.L. & $\begin{array}{l}\text { Blasco Claret, } \\
\text { Victor }\end{array}$ & $\begin{array}{l}\text { Sistema de impresión en azulejos cerámicos (Translation: Printing } \\
\text { system for ceramic tiles) }\end{array}$ & $06 / 06 / 2008$ \\
\hline $\begin{array}{l}\text { MACCARIAN- } \\
\text { TONIO }\end{array}$ & Maccari Antonio & Plant and method for decoration by means of ink-jet technology & $08 / 1 \mathrm{I} / 2006$ \\
\hline ARGON HT SRL & $\begin{array}{l}\text { Manoukian Ha- } \\
\text { rutiun }\end{array}$ & Screen printing machine having a replaceable IJP unit & $04 / 06 / 2002$ \\
\hline KERAJET SA & $\begin{array}{l}\text { Tomas Clara- } \\
\text { monte, J.:Vicent } \\
\text { Abella, Rafael; }\end{array}$ & $\begin{array}{l}\text { Sistema de mantenimiento de máquinas de impresión por chorro de } \\
\text { tinta, de gran formato } \\
\text { (Translation: Maintenance system for ink-jet printing machines for } \\
\text { large formats) }\end{array}$ & $09 / 02 / 2009$ \\
\hline
\end{tabular}

Table 2. IJP devices and machines patented for decorating in ceramic tile industry (in colour grey the Spanish contribution) 